\title{
Effect of polyamines and natural growth substances on the growth and flowering of rose (Rosa hybrida) cv. Samurai under protected conditions
}

\author{
Sumathi Tatte ${ }^{1}$, Alka Singh ${ }^{1 *}$ and T. R. Ahlawat ${ }^{2}$ \\ ${ }^{1}$ Department of Floriculture and Landscape Architecture, ACHF, Navsari Agricultural University, Navsari-396450 \\ (Gujrat), INDIA \\ ${ }^{2}$ Department of Fruit Science, ACHF, Navsari Agricultural University, Navsari-396450 (Gujrat), INDIA \\ *Corresponding Author. E-mail : dralkasinghdhaka@gmail.com
}

Received: August 19, 2015; Revised received: May 08, 2016; Accepted: July 22, 2016

\begin{abstract}
Investigations were conducted to study the effect of different polyamines and natural growth substances as a pre harvest foliar spray on greenhouse rose cv. Samurai. The study involved preharvest foliar spraying with polyamines like spermine $(10 \mathrm{ppm})$ and spermidine $(10 \mathrm{ppm})$; natural growth substances like enriched banana pseudostem sap ( 1 per cent) and cow urine ( 2 per cent). All the treatments improved the vegetative and flowering characters over control. However, among different treatments, foliar spray of spermine $10 \mathrm{ppm}$, followed by spermidine $10 \mathrm{ppm}$ were highly significant in influencing all vegetative parameters like plant height $(79 \mathrm{~cm})$, number of branches per plant (3.73), stem girth $(10.69 \mathrm{~mm})$, number of leaves per plant $(91.33)$, leaf area $\left(14.68 \mathrm{~cm}^{2}\right)$ and leaf chlorophyll content $(36.96 \mathrm{mg} / \mathrm{g})$. Further, flowering parameters like flower stalk length $(61.24 \mathrm{~cm})$, bud length $(2.70 \mathrm{~mm})$, flower diameter $(6.50 \mathrm{~cm})$, number of petals per flower (55.90) and vase life (6.63 days) were significantly maximum in plants sprayed with spermine $10 \mathrm{ppm}$. The treatment of foliar spray with spermine and spermidine almost doubled the flower production and improved the flower quality in tems of bud size and vase life as compared to control.
\end{abstract}

Keywords: Enriched banana pseudostem sap, Polyamines, Rose, Spermine, Spermidine

\section{INTRODUCTION}

Protected cultivation of flower crops is a leading industry in India and has the potential to change the scenario of Indian floriculture (Ramalingam, 2008 and Patel et al. 2014). Among the cut flowers grown in India primarily for export, rose tops the area grown under protected conditions (Sudhagar et al.2013). Though roses occupy the top places in all international cut flower markets, competitions are very intensive where quality plays a priority role. A fierce competition exists in the international flower market with regard to flower quality wherein pre and post harvest handling techniques can play important role (Tatte et al., 2015). The causes of this low quality can be primly attributed to non-adoption of scientific management practices namely; low quality planting material, improper nutritional and plant protection practices and lack of technical knowledge regarding the various crop regulation and post harvest practices (Sharma et al., 2001). Polyamines comprising of spermine, spermidine and putrescine form a new class of aliphatic amines that are ubiquitous in living organisms and they are involved in many plant developmental processes, including cell division, embryogenesis, reproductive organ development, root growth, tuberization, floral initiation and development (Galston et al., 1997; Bais and Ravishankar, 2002). PAs and their biosynthetic enzymes are associated with rapid cell division in many plant systems viz., carrot embryogenesis (Montague et al., 1978), tomato ovaries (Heimer and Mizrahi, 1982), tobacco ovaries (Slocum and Galston, 1985), fruit development (Kakkar and Rai, 1993) and other plant species (Bias and Ravishankar, 2002). High levels of endogenous PAs and their conjugates have also been found in apical shoots and meristems prior to flowering (Cabanne et al., 1981). Significant effect of Putrescine on flower yield and chemical composition in Chrysanthemum has been reported (Mahros et al., 2011). Further, increased flowering parameters like flower stalk length, flower bud diameter, bud height, fresh weight of flower stalk and vase life of rose flower with spermidine has been observed in rose (Farahi et al., 2012). Banana pseudo stem sap has some special properties relating to various growth phenomena and is a potential source of cellulose, consisting of different phytochemicals. It is a novel organic liquid fertilizer and has a rich source of macro and micro nutrients comprising of $\mathrm{N}-280 \mathrm{mg} / \mathrm{l}, \mathrm{P}-15 \mathrm{mg} / \mathrm{l}$, K-3200mg/l, Ca- 90mg/l, Mg-400mg/l, S-210mg/l, Fe8.2mg/l, Mn-6.5mg/1, Zn-1.43mg/l, Cu-0.52mg/l (Patil, 2008). Banana pseudo stem enriched sap contains growth regulators like $\mathrm{GA}_{3}$ and cytokynin apart from essential plant nutrients. Influence of polyamines and natural growth substances on cut flower crops under protected conditions has not been extensively studied 
in India. Hence, this experiment was planned to study the influence of polyamines (spermine, spermidine and putrescine) and natural growth substances (cow urine and enriched banana pseudostem sap) spray on vegetative and floral growth of rose (Rosa hybrida) plants with the basic objective to obtain improved flower quality of cut roses.

\section{MATERIALS AND METHODS}

Location:The experiment was conducted under naturally ventilated polyhouse at greenhouse complex, Department of floriculture and landscape architecture, Navsari agricultural university, Navsari, Gujarat, India. Crop and variety: The research work was carried out in a Hybrid Tea rose variety 'Samurai'. The variety is suitable to tropical conditions.

Preharvest spray of chemicals and natural growth substances: The experiment was laid out with five treatments in a randomized block design (RBD) with three replications. One year old uniform budded rose plants of cv. Samurai grown on raised beds in polyhouse were used to study. The study involved with preharvest spray treatments with Spermine (10 ppm), Spermidine $(10 \mathrm{ppm})$, Enriched banana pseudostem sap (1\%), cow urine $(2 \%)$ and controls. Plots were sprayed with treatments 15 days after pruning and repeated after 15 days interval.

Measurement of traits: Traits were measured as following: plant height, length of flower stalk by ruler, leaf area by digital leaf area meter, bud length, bud diameter, flower diameter by vernier calipers. Bud diameter and bud length were measured at tight bud stage while flower diameter was measured at fully opened flower stage. Number of flowers per plant were counted based on flowering in one month obtained after regular pinching and bending practices. Number of branches per plant, number of leaves per stalk, petals per flower and vase life (days to wilting) were counted and recorded.

Chlorophyll content (mg/g):The total chlorophyll content was determined by following the method of Yoshida et al., (1971) and expressed in $\mathrm{mg} / \mathrm{g}$ of fresh weight.

Statistical analysis: The statistical analysis was done by adopting the standard procedures of Panse and Sukhatme (1985) and the results were interpreted.

\section{RESULTS AND DISCUSSION}

In the present study, rose plants sprayed with polyamines and natural growth substances, showed good vegetative and floral growth compared to untreated plants. Among all the treatments studied, plants sprayed with $10 \mathrm{ppm}$ spermine exhibited maximum plant height $(79.00 \mathrm{~cm})$, number of branches (3.73), number of leaves $(91.33)$, leaf area $\left(14.68 \mathrm{~cm}^{2}\right)$, followed by plants sprayed with 10 ppm spermidine. Further, polyamines play roles such as a new class of plant growth regulators, Hormonal Second Messengers (HSM) and one of the reserves of carbon and nitrogen (Galston and kaur-Sawhney, 1997). Polyaminesform a class of aliphatic amines that are ubiquitous in plants and have been implicated in wide range of biological processes, including cell division, protein synthesis, DNA replication, differentiation and rhizogenesis (Tabor and Tabor, 1984; Smith, 1985; Van Broeck et al., 1994). Further, direct relationship of polyamines has been established with $\mathrm{N}$ (Zhang et al. 2013)), P (Hewitt, 1963, Aldesuquy et al., 2014) and K (Amri et al. 2011)). Spermine and spermidine seem to mediate sensing signal mechanisms and gene players via $\mathrm{N}$ assimilation and carbon metabolism in different plant organs (Foyer et al., 2002; Scheible et al., 1997; Scheible et al., 2000). The positive effect of polyamines on growth has also been earlier attributed to enhanced cell division and expansion (Cohen, 1988). Significantly maximum chlorophyll $(3.96 \mathrm{mg} / \mathrm{g})$ content was observed in plants sprayed with spermine 10 ppm, which was followed by spermidine $10 \mathrm{ppm}(3.65$ $\mathrm{mg} / \mathrm{g}$ ) as compared to control $(1.95 \mathrm{mg} / \mathrm{g})$. Exogenous application of polyamines in carnation has been also shown to retard chlorophyll loss and senescence in carnation (Lee et al., 1997). Further, increase in the chlorophyll content in leaves was found due to foliar application of polyamines in gladiolus (Nahed et al., 2009) and in chrysanthemum (Mahros et al., 2011). Foliar application of polyamines have earlier shown toto promote vegetative growth in matthiola (Youssef et al., 2004), in periwinkle (Iman et al., 2005), in Di-

Table 1. Effect of different polyamines and natural preservatives as pre harvest spray on vegetative growth of rose cv. Samurai.

\begin{tabular}{|c|c|c|c|c|c|c|}
\hline Treatments & $\begin{array}{c}\text { Plant } \\
\text { height } \\
(\mathrm{cm})\end{array}$ & $\begin{array}{l}\text { Number of } \\
\text { branches }\end{array}$ & $\begin{array}{l}\text { Stem girth } \\
\quad(\mathrm{mm})\end{array}$ & $\begin{array}{l}\text { Number of } \\
\text { leaves }\end{array}$ & $\begin{array}{c}\text { Leaf area } \\
\left(\mathrm{cm}^{2}\right)\end{array}$ & $\begin{array}{l}\text { Chlorophyll } \\
\text { content }(\mathrm{mg} / \mathrm{g})\end{array}$ \\
\hline $\mathrm{T}_{1}$ Spermine @10 ppm & 79.00 & 3.73 & 10.69 & 91.33 & 14.68 & 3.96 \\
\hline $\mathrm{T}_{2}$ Spermidine @10 ppm & 70.36 & 3.03 & 9.60 & 61.67 & 10.07 & 3.65 \\
\hline $\begin{array}{l}\mathrm{T}_{3} \text { Enriched banana pseu- } \\
\text { dostem sap @ } 1 \%\end{array}$ & 63.93 & 2.77 & 9.40 & 42.00 & 11.29 & 3.03 \\
\hline $\mathrm{T}_{4}$ Cow urine @ $2 \%$ & 69.64 & 2.00 & 9.58 & 31.33 & 8.03 & 2.89 \\
\hline $\mathrm{T}_{5}$ Control & 65.00 & 1.80 & 9.15 & 32.33 & 8.55 & 1.95 \\
\hline S.Em \pm & 2.09 & 0.10 & 0.30 & 1.80 & 0.34 & 0.09 \\
\hline CD $5 \%$ & 6.82 & 0.34 & 0.97 & 5.88 & 1.12 & 0.30 \\
\hline $\mathrm{CV} \%$ & 5.20 & 6.69 & 5.32 & 6.04 & 5.63 & 5.11 \\
\hline
\end{tabular}


Table 2. Effect of different polyamines and natural preservatives as pre harvest spray on flowering of rose cv. Samurai.

\begin{tabular}{lccccccc}
\hline \multicolumn{1}{c}{ Treatments } & $\begin{array}{c}\text { Length of } \\
\text { flower } \\
\text { stalk }(\mathbf{c m})\end{array}$ & $\begin{array}{c}\text { Number } \\
\text { of flow- } \\
\text { ers }\end{array}$ & $\begin{array}{c}\text { Bud } \\
\text { length } \\
\text { (cm) }\end{array}$ & $\begin{array}{c}\text { Bud } \\
\text { diame- } \\
\text { ter }(\mathbf{c m})\end{array}$ & $\begin{array}{c}\text { Flower } \\
\text { diameter } \\
\text { (cm) }\end{array}$ & $\begin{array}{c}\text { Number of } \\
\text { petals per } \\
\text { flower }\end{array}$ & $\begin{array}{c}\text { Vase life } \\
\text { (Days) }\end{array}$ \\
\hline $\mathrm{T}_{1}$ spermine @ 10 ppm & 61.24 & 6.19 & 2.70 & 2.60 & 6.50 & 55.90 & 6.63 \\
$\mathrm{~T}_{2}$ spermidine @ 10 ppm & 57.20 & 6.00 & 2.50 & 2.14 & 6.36 & 53.18 & 6.53 \\
$\mathrm{~T}_{3}$ Enriched banana pseu- & 53.18 & 5.53 & 2.34 & 2.02 & 6.30 & 48.82 & 6.47 \\
dostem sap @ 1\% & 48.13 & 4.53 & 2.26 & 1.91 & 6.13 & 41.65 & 6.40 \\
$\mathrm{~T}_{4}$ cow urine @ 2 \% & 39.83 & 3.36 & 2.10 & 1.60 & 5.89 & 40.43 & 5.98 \\
$\mathrm{~T}_{5}$ control & 1.13 & 0.15 & 0.06 & 0.07 & 0.09 & 0.84 & 0.09 \\
S.Em+ & 3.67 & 0.49 & 0.20 & 0.22 & 0.28 & 2.74 & 0.28 \\
CD 5\% & 3.76 & 5.07 & 4.54 & 5.65 & 3.13 & 3.03 & 3.13 \\
CV \% & & & & & & \\
\hline
\end{tabular}

anthus caryophyllus and Dahlia pinnata (Mahgoub et al., 2006, 2011) and in gladiolus (Nahed et al., 2009).

Foliar application of spermine and spermidine both, showed significant effect on floral attributes in rose in the present study. Different flowering characters like length of flower stalk $(61.24 \mathrm{~cm})$, length of bud $(6.19$ $\mathrm{cm})$, flower diameter $(6.50 \mathrm{~cm})$, number of petals per flower (55.90), number of flowers per plant (6.19) and vase life (6.63) were found to be significantly maximum with the application of $10 \mathrm{ppm}$ spermine, followed by $10 \mathrm{ppm}$ spermidine as compared to control with $39.83 \mathrm{~cm}$ flower stalk, 3.36 number of flowers, $2.1 \mathrm{~cm}$ bud length, $1.6 \mathrm{~cm}$ bud diameter, $5.89 \mathrm{~cm}$ flower diameter, number of petals (40.43) and 5.98 days of vase life. Conjugated polyamines are known to be associated with the physiology of flowering metabolite synthesis (Slocum and Galston, 1985). Correlation between polyamines and flowering processes has been observed earlier in cherries (Wang et al., 1985) and in Arabidopsis (Applewhite et al., 2000).High levels of endogenous polyamines and their conjugates have been known to be found in apical shoots and meristems prior to flowering in tobacco (Cabanne et al., 1981) and flower parts of many plants (Martin- Tanguy, 1985). Further, Farahi et al., (2012) reported improved stalk length, length of bud and bud diameter with foliar application of spermidine in rose plants. Beneficial effects of polyamines on flower parameters have also been reported in chamomile plant (Wahed et al., 2004), datura (Youssef et al., 2004), carnation (Mahagoub et al., 2006), gladiolus (Nahed et al., 2009) and chrysanthemum (Mahros, et al., 2011).

\section{Conclusion}

In the present investigation, significant role of a new class of growth hormone, polyamines viz., spermine and spermidine in overall plant growth and development in rose plants has been found. The treatment comprising of foliar application of $10 \mathrm{ppm}$ of spermine and $10 \mathrm{ppm}$ of spermidine were highly effective in influencing plant growth and improving flower parameters in rose plants. Number of branches, number of leaves, leaf area, chlorophyll content and number of flowers were almost doubled in plants and flower qual- ity was significantly improved with $10 \mathrm{ppm}$ spermine and spermidine foliar spary as compared to control..

\section{REFERENCES}

Aldesuquy, H., Haroun, S., Hamed, S. A., Saied, A. W. E. (2014). Involvement of spermine and spermidine in the control of productivity and biochemical aspects of yielded grains of wheat plants irrigated with waste water. Egyptian Journal of Basic and Applied Sciences: 16-28.

Applewhite, P. B. Kaur-Sawhney, R. and Galston, A. W. (2000). A role of spermidine in the bolting and flowering of Arabidopsis. Plant Physiol., 79: 635-640.

Amri, E. Mirzaei, M. Moradi, M. and Zare, K. (2011). The effects of spermidine and putrescine polyamines on growth of pomegranate (Punica granatum L. cv 'Rabbab') in salinity circumstance. International Journal of Plant Physiology and Biochemistry Vol. 3(3), pp. 43-49.

Bias, H. P. and Ravishankar, G. A. (2002). Role of polyamines in the ontogeny of plants and their biotechnological applications. Plant Cell, Tissue and Organ Culture. 69: 1-34

Cabanne, F. Dalebroux, M.A. Martin-Tanguy, J. and Martin, C. (1981). Hydroxycinnamic acid amides and ripening to flower of Nicotiana tabacum L. var. Xanthi n.c. Physiol Plant. 53: 399-404.

S.S. Cohen (1988). A guide to the polyamines. Oxford Univ. Press, Oxford.

Farahi, H. F., Khalingi, A., Kholdbarin, B., Akbar-boojar, M. M. Eshghi, S. Kavoosi, B. and Aboutalebi, A. (2012). Influence of exogenous spermidine on quality properties and vase life of rose (Rosa hybrida cv. Dolcvita). Annals of Biological Research, 3(10): 4758-4763.

Foyer, C. H. and Noctor (Eds.), (2002). Photosynthetic nitrogen assimilation and associated carbon and respiratory metabolism, Kluwer Acad, Publ., Boston.

Galston, A. W., Kaur-Sawhney, R., Altabella, T. and Tiburcio, A. F. (1997). Plant polyamines in reproductive activity and response to abiotic stress. Bot. Acta. 110: 197-207.

Heimer, Y. M. and Mizrahi,Y. (1982) characterization of ornithine decorboxylase of tobacco cells and tomato ovaries. Biochem J., 201: 373-376.

Hewitt,E.J. (1963). The essential nutrients elements : Requirements and interactions in plants. In: Steward, F.C. (ed). Plant Physiol. Atreatise, Academic, NY, pp. 137-360.

Iman, T. M., Bekheta, M. A. and Mahagoub, M. M. (2005). Physiological response of periwinkle plants (Catharanthus roseus L.) to tryphtophan and putrescine. 
Int. J. Agric. Biol., 7: 210-213.

Kakkar, R. K. and Rai, V. K. (1993). Plant polyamines in flowering and fruit ripening. Phytochem. $33: 1281-1288$.

Lee, M. M., Lee, S. H. and Park, K. Y. (1997). Effects of spermine on ethylene biosynthesis in cut carnation (Dianthus caryophyllus L.) flowers during senescence. J. Plant Physiol., 151: (68-73).

Mahgoub, M. H., Abdelaziz, N. G. and Mazhar, M. A. (2011). Response of Dahlia pinnata L. plant to foliar spray with putrescine and thiamine on growth, flowering and photosynthetic pigments. American-Eurasian J. Agric. And Environ, Sci., 10 (5): 769-775.

Mahagoub, H., Mona El-Ghorrab and Bekheta. (2006). Effect of some bioregulators on the endogenous phytohormones, chemical composition, essential oil and its antioxidant activity of carnation (Dianthus caryophyllus L.). J. Agric. Sci. Mansoura Univ., 31 (7): 4229-4245.

Mahros, K. M. M., El-Saady, M.B., Mona, H. M., Afaf, M. H. and Iman, M. E. (2011). Effect of putrescine and uniconazole treatments on flower characters and photosynthetic pigments of Chrysanthemum indicum L. plant, J. of American Science, 7 (3): 399-408.

Martin - Tanguy, J. (1985). The occurrence and possible function of hydroxycinnamoyl acid amides in plants. Plant Growth Regul. 3: 381-399.

Montague, M. J. Koppenbrink, J. W. and Jaworski, E. G. (1978). Polyamine metabolism in embryonic cells of Daccus carota. Plant Physiol., 62: 430-433.

Nahed, A. A. G. Taha Lobna and Ibrahim Soad, M. M. (2009). Some studies on the effect of putrescine, ascorbic acid and thiamine on growth, flowering and some chemical constituents of gladiolus plants at Nubaria. Ozean Journal of Applied Science, 2(2): 1943-2429.

Panse, V. G. and Sukhatme, P. V. (1985). Statistical methods for agricultural workers. Indian Council of Agricultural Research, New Delhi

Patel, N.L., Ahlawat, T.R. and Alka Singh. (2014). Status and Scenario of Horticulture Growth and Development in India and in the World. Global conference on technological changes and human resources for climate smart horticulture - Issues and strategies. pp- 109-117. $28^{\text {th }}-31^{\text {st }}-$ May, Navsari Agricultural University, Navsari, India.

Patil, A. P. (2008). Nutrient, banana pseudostem sap and sucker management in ratoon banana under drip irrigation. M.Sc. Thesis submitted at NAU.

Ramalingam, K. (2008). Effect of growth regulating substances on growth, yield and post harvest quality of cut Rose cv. Happy Hour, M.Sc. (Hort.) Thesis, Tamil Nadu Agricultural University, Coimbatore.

Scheible, W. R., Gonzales-Fontes, L. M., Muller-Rober, B. , Caboche, M. and Stitt, M. (1997). Nitrate acts as a signal to induce organic acid metabolism in tobacco. Plant cell. 9: 783-798.

Scheible, W.R., Krapp, A. and Stitt, M. (2002). Reciprocal diurnal changes of phosphoenolpyruvate carboxylase expression and cytosolic pyruvate kinase, citrate synthase and NADP - isocitrate dehydrogenase expression regulate organic acid metabolism during nitrate assimilation in tobacco leaves. Plant Cell Environ. 22: 11551167.

Sharma, C. P., Maurya, A. N.,Srivastava, O. P. and Ashok, M. (2001). Role of GA3, maleic hydrazide and ethrel in modifying vegetative and floral characters of Chrysanthemum morifolium. The Orissa J. Hort. 29(2): 35-40.

Slocum, R. D. and Galston, A. W. (1985). Changes in polyamines associated with past fertilization and development in tobacco ovary tissue. Plant Physiol. 79: 336343.

Smith, T. A. (1985). Polyamines. Annu. Rev. Plant Physiol. 36: 1611-1613.

Sudhagar, S. (2013). Production and marketing of cut flower (Rose and gerbera) in Hosur Taluk. Int. J. Business \& Management Invention. 2 (5): 15-25.

Tabor, C. W. and Tabor, H. (1984). Polyamines. Annu. Rev. Biochem. 53: 749-790.

Tatte, S., Alka Singh and Ahlawat, T. R. (2015) effect of polyamines on postharvest quality and vaselife of rose var. samurai. The Bioscan: 10(2): 675-678.

Van den Broeck, D., Van Den, S. D., Van Montague, M. and Caplan, A. (1994). A group of chromosomal proteins in specifically released by spermine and loses DNA-binding activity upon phosphorylation. Plant Physiol., 106: 559-566.

Wahed, A. A. M. S. A., Karima, M. and Din, G. E. (2004). Stimulation effect of spermidine and stigmasterol on growth, flowering, biochemical constituents and essential oil of Chamomile plant. (Chamomilla reticulate L., Raush). Bulg. J. Plant Physiol., 30 (3-4): 48-60.

Wang, S. Y. M., Faust and Steffens, G. L. (1985). Metabolic changes in cherry flower buds associated with breaking of dormancy in early and late blooming cultivars. Physiol. Plant., 65: 89-94.

Yoshida, S.,Forno, D. S. , Cock, J. H. and Gomez, K. A. (1971). Laboratory manual for physiological studies of rice. IRRI, Philippines. pp.1- 43.

Youssef, A. A., Mona, H. M. and Iman, M. T. (2004). Physiological and biolochemical aspects of Matthiola incana L. plants under the effect of putrsescine and kinetine treatments. Egypt. J. App. Sci., 19 (9B).

Yi Zhang, Xiao-Hui Hu , Yu Shi, Zhi-Rong Zou, Fei Yan, Yan-Yan Zhao, Hao Zhang, and Jiu-Zhou Zhao (2013). Beneficial Role of Exogenous Spermidine on Nitrogen Metabolism in Tomato Seedlings Exposed to Saline-alkaline Stress. J. Amer. Soc. Hort. Sci. 138 (1):38-49. 